\title{
Exposure to nickel compounds and smoking in relation to incidence of lung and nasal cancer among nickel refinery workers
}

\author{
Aa Andersen, S R Berge, A Engeland, T Norseth
}

\begin{abstract}
Objectives-To investigate the relation between occupational hazards among nickel refinery workers and their exposure to different forms of nickel over time and the interaction between smoking and total exposure to nickel.

Methods-The cohort consisted of 379 workers with first employment 1916-40 and at least three years of employment and 4385 workers with at least one year of employment 1946-83. Data on smoking (ever or never) were available for almost $95 \%$ of the cohort. Two analyses were used, indirect standardisation from observed and expected numbers and Poisson regression.

Results-During the follow up 1953-93, 203 new cases of lung cancer were observed $v 68$ expected (standardised incidence ratio (SIR) $3 \cdot 0,95 \%$ confidence interval $(95 \% \mathrm{CI}) 2 \cdot 6-3 \cdot 4)$ and 32 cases of nasal cancer were observed $v 1.8$ expected (SIR 18.0, 95\% CI 12-25). The Poisson regression analysis showed an excess risk of lung cancer in association with exposure to soluble forms of nickel, with a threefold increase in relative risk (RR) $(P<0.001)$ and a multiplicative effect of smoking and exposure to nickel. The RRs were $1 \cdot 1(95 \%$ CI $0 \cdot 2-5 \cdot 1)$ for exposed workers who had never smoked and $5 \cdot 1$ (95\% CI 1.3-20.5) for exposed workers who smoked.

Conclusion-It is not possible to state with certainty which specific nickel compounds are carcinogenic, but a significant excess risk was found for workers exposed to soluble nickel alone or in combination with other forms of nickel. The present study suggests a multiplicative effect of smoking and nickel exposure.
\end{abstract}

The Cancer Registry of $\mathrm{Aa}$ Andersen

A Engeland

Falconbridge Nickel

Refinery,

Kristiansand, Norway

S R Berge

Institute of

Occupational Health, Oslo, Norway

T Norseth

Correspondence to: Dr Aage Andersen, The Cancer Registry of Norway, Montebello, N-0310 Oslo, Norway.

Accepted 10 May 1996

This paper is dedicated to Dr A C Høgetveit. oxidic nickel as in the studies from Canada and Norway. ${ }^{46}$ The two Norwegian studies ${ }^{56}$ also indicated an increased risk of lung cancer among workers in the electrolysis departments implicating soluble forms of nickel. These findings were in contrast to those from Canada, where similar types of work were not associated with an increased risk of lung cancer. $^{7}$

In 1985, an International Committee on Nickel Carcinogenesis in Man chaired by Sir Richard Doll was formed with the aim of identifying those forms of nickel that are carcinogenic and of establishing dose-exposure relations. Measurements of total nickel were used as a basis for estimates over time for four nickel compounds (metallic nickel, oxidic nickel, sulphidic nickel, and soluble nickel salts). The Committee concluded that more than one form of nickel may give rise to lung and nasal cancer and that exposure to soluble nickel also increases the risks for these cancers. ${ }^{8}$ The International Agency for Research on Cancer (IARC) evaluated the carcinogenicity of nickel in $1990 .{ }^{9}$ All nickel compounds except metallic nickel were classified as carcinogenic to humans in the IARC's overall evaluation. The evaluation was based on epidemiological studies, carcinogenicity studies in experimental animals, and in vitro studies, supported by the underlying concept that nickel compounds can generate nickel ions at critical sites in their target cells. ${ }^{111}$

It is still not known with certainty what compound or compounds constitute the cancer risk in human, as workers are not exposed exclusively to either soluble or insoluble forms. Soluble nickel compounds do not seem to induce injection site tumours, and nickel subsulphide and beta-nickel monosulphide are the most potent carcinogens in such experiments. ${ }^{9}$ Considerable differences in tumorigenic potency have been shown, among slightly soluble forms of nickel compounds. ${ }^{12}$ Inhalation of soluble nickel compounds has not been reported to cause cancer in experimental animals. Dunnick et $a l,^{13}$ in an inhalation study, recently reported significant increase in lung tumours in rats exposed to nickel subsulphide and nickel oxide, but no such findings for nickel sulphate hexahydrate. Inhalation studies of nickel oxide in rats and hamsters did not increase the occurrence of respiratory tumours, but both nickel oxide and metallic nickel dust induced tumours after intratracheal instillation. ${ }^{9}$ Binding to DNA and to nuclear proteins and generation of reactive oxygen species are suggested mechanisms for the carcinogenic effect of nickel compounds. The results of experiments in animals and in vitro thus indicate that slightly soluble com- 
pounds are more active than soluble salts, ${ }^{14}$ but workers in this industry have generally been exposed more intensely to particles than to soluble forms of nickel. ${ }^{8}$

As smoking is the most important cause of lung cancer, a possible interaction between smoking and occupational exposure must be taken into account, particularly for a high risk group such as nickel refinery workers. In our study reported in $1982^{6}$ the precision of the estimate of the excess risk of lung cancer caused by smoking among nickel workers was not high, and the effects were close to being additive rather than multiplicative. The aim of the present study was to investigate changes in the occupational risk of lung and nasal cancer over time, dose-exposure relations between different forms of nickel, and to evaluate the interactions between smoking and exposure to nickel.

\section{Material and methods \\ MATERIAL}

A cohort of male employees working at the Falconbridge nickel refinery during the period 1916-83 was established. The study population consisted of: (1) 379 workers who had started work during the period 1916-40 and who had three years or more of total employment and were included in our first two studies and (2) all 4385 workers who started work in the period 1946-83 and who had one or more years of total employment. Both files contained the name, date of birth, and dates of beginning and final end of employment. For each period of employment, the date of entry and date of the end were coded for 82 different working areas, defined as a department, or as a group of workers with the same type of job in a department. The study was confined to employees alive at the beginning of the follow up period on 1 January 1953.

Data on smoking habits were collected by the medical department at the refinery, from the medical records for 4605 workers, and from colleagues for 159 workers (128 ever smokers and 31 never smokers). The material was divided into two groups only: those who had never smoked and those who were present or past smokers. Data were available for almost $95 \%$ of the workers; $76 \%$ had smoked at some time, which is a higher percentage than in the same age group in the general male population. ${ }^{15}$

In Norway, a survey based on a questionnaire on smoking habits was carried out in $1964-5$ in a $0.5-1.0 \%$ sample of the Norwegian male population born 1893-1927 (12000 men). ${ }^{16}$ This material was also divided into those who had never smoked and those who had smoked.

\section{METHODS}

The study population was followed up for cancer incidence, date of emigration, and death from the beginning of 1953 to the end of 1993. The follow up started after three years of total employment for those with first entry 1916-40, or if first entry was in 1946 or later; the follow up started after one year of total employment. People who died or who emigrated were followed up to the time of these events.

The Cancer Registry has records of all new cases of cancer in Norway since 1953. The registration is based on compulsory reporting from hospitals and histopathological laboratories, and less than $1 \%$ of all cases are based on death certificates alone. Since the census of 1960, a personal identification number has been given to all inhabitants of the country. This number was used in this study; matching of all deaths and cancer morbidity after 1960 was therefore fully automated, but had to be done manually for the preceding years.

The study was based on a comparison of observed and expected incidence of cancer. The five-year age specific incidences for each year from 1953 to 1993 for the entire Norwegian male population were used to estimate the expected number of new cases. Standardised incidence ratios (SIRs) were calculated for all cancer and for selected types of cancer. For all SIRs, 95\% confidence intervals (95\% CIs) were calculated by assuming a Poisson distribution for the observed number of cancer cases. A result was regarded as significant if 1.0 was not included in the $95 \% \mathrm{CI}$ for the SIR. The data analysis was performed with the Epicure program package. ${ }^{17}$

The study of interaction between smoking in the general population and smoking and exposure to nickel was restricted to nickel refinery workers with the same birth cohorts as the general population (1893-1927) and the same follow up period (1966-92). Only workers first employed before 1966 and with a cumulative exposure of $\geqslant 1 \mathrm{mg} / \mathrm{m}^{3}$ year of total nickel were included (1337 workers). The cohort of nickel refinery workers was compared with the population sample by multivariate Poisson regression analysis. ${ }^{18}$ As well as smoking habits and exposure to nickel, variables for age and birth cohort were included in the model.

ESTIMATION OF EXPOSURE TO NICKEL

We based our estimates of exposure to different forms of nickel on the Hybinette process, ${ }^{19}$ which was used at the refinery from 1910 until 1978. A description of the process after that period and details of the exposures were given by Doll $e t a l,{ }^{8}$ and derivations from the original exposure matrix are described in more detail.

Several measurements of atmospheric nickel were made in most process areas at the refinery in 1973, but few measurements were available before that year. Some measurements were, however, obtained in $1964,{ }^{20}$ and others were made in the roasting and smelting working areas in 1952-3. All of these data were the basis for the estimates used in this study. The concentrations of total airborne nickel and the different forms present in all periods were estimated by a group of engineers, medical personnel with experience in occupational medicine, and others with long experience at the refinery; researchers from the Institute of Occupational Health and the 
Table 1 Observed and expected numbers of new cases of cancer among 4764 male nickel refinery workers; follow up 1953-93

\begin{tabular}{llrrrr}
\hline Type of cancer & ICD-7 code & Obs & Exp & \multicolumn{1}{c}{$S I R$} & $95 \%$ CI \\
\hline Stomach & 151 & 45 & $48 \cdot 2$ & $0 \cdot 9$ & $0 \cdot 7-1 \cdot 3$ \\
Colon/rectum & $153-154$ & 76 & $69 \cdot 2$ & $1 \cdot 1$ & $0 \cdot 9-1 \cdot 4$ \\
Nose and nasal cavity & 160 & 32 & $1 \cdot 8$ & $18 \cdot 0$ & $12 \cdot 3-25 \cdot 4$ \\
Larynx & 161 & 11 & $7 \cdot 0$ & $1 \cdot 6$ & $0 \cdot 8-2 \cdot 8$ \\
Lung (excluding & & & & & \\
No 162.2) & 162 & 203 & $68 \cdot 3$ & $3 \cdot 0$ & $2 \cdot 6-3 \cdot 4$ \\
Pleura & $162 \cdot 2$ & 3 & $1 \cdot 9$ & $1 \cdot 6$ & $0 \cdot 3-4 \cdot 6$ \\
Prostate & 177 & 129 & $91 \cdot 1$ & $1 \cdot 4$ & $1 \cdot 2-1 \cdot 7$ \\
Testis & 178 & 7 & $7 \cdot 8$ & $0 \cdot 9$ & $0 \cdot 4-1 \cdot 8$ \\
Kidney & 180 & 19 & $19 \cdot 6$ & $1 \cdot 0$ & $0 \cdot 6-1 \cdot 5$ \\
Bladder & 181 & 33 & $36 \cdot 2$ & $0 \cdot 9$ & $0 \cdot 6-1 \cdot 3$ \\
Malignant melanoma & 190 & 21 & $17 \cdot 3$ & $1 \cdot 2$ & $0 \cdot 8-1 \cdot 9$ \\
Brain & 193 & 12 & $15 \cdot 7$ & $0 \cdot 8$ & $0 \cdot 4-1 \cdot 3$ \\
Haematopoietic tissues & $200-207$ & 34 & $43 \cdot 0$ & $0 \cdot 8$ & $0 \cdot 6-1 \cdot 1$ \\
Other specified sites & & 95 & $82 \cdot 6$ & $1 \cdot 2$ & $0 \cdot 9-1 \cdot 4$ \\
Unspecified sites & 199 & 29 & $21 \cdot 5$ & $1 \cdot 4$ & $0 \cdot 9-1 \cdot 9$ \\
All sites & $140-207$ & 749 & $531 \cdot 2$ & $1 \cdot 4$ & $1 \cdot 3-1 \cdot 5$ \\
\hline
\end{tabular}

Cancer Registry also participated. All estimates made by the expert group for the 82 different work areas were discussed and accepted by the union as well as by the management before the analysis.

It was assumed that the nickel species occurred in respirable dust in the same proportion as in the material being handled in various work areas. Even for periods for which samples were available, the analyses included total nickel only. Nickel species were divided into four categories: metallic nickel, oxidic nickel, soluble nickel, and sulphidic nickel (subsulphide). Insoluble nickel was considered to include metallic nickel, oxidic nickel, and sulphidic nickel, and soluble nickel was considered to consist primarily of nickel sulphate and nickel chloride, and also of nickel carbonate and nickel hydroxide.

As very few measurements were available before the 1970s; eight hour time weighted average (TWA) nickel concentrations were estimated as low $0.1-0.4 \mathrm{mg} / \mathrm{m}^{3} /$ year, medium $0.5-1.9 \mathrm{mg} / \mathrm{m}^{3} /$ year, high $2.0-8.0 \mathrm{mg} / \mathrm{m}^{3} /$ year, and very high $>8 \mathrm{mg} / \mathrm{m}^{3} /$ year. The mean concentration for each category was taken to be the average of the extremes of the range, except in the highest category, in which $10 \mathrm{mg} / \mathrm{m}^{3} /$ year was taken as the mean concentration. All cumulative nickel estimates were calculated in $\mathrm{mg} / \mathrm{m}^{3}$ year and presented as $\mathrm{mg} / \mathrm{m}^{3}$ for total nickel, soluble nickel, and nickel oxide. We used the same method for estimation of exposure as that used by Doll et $a l^{8}$ in the following working areas: unloading and crushing; smelting and calcining; stack repairs; technical administration and mechanics; and electrolysis departments. In certain departments modified estimations were used. Men who worked in laboratories, gas cleaning, the filtercloth shop, and the pilot plant were exposed to low levels of nickel throughout the period; they were thus attributed an exposure to nickel of $0.1 \mathrm{mg} / \mathrm{m}^{3} /$ year. For employees in all other working areas including most of the maintenance departments zero was used in the exposure matrix. It is well known that some of these maintenance workers have also been exposed to nickel to some extent, but no measurements exist.

As the level of exposure varied over time, estimates were given for four technological periods when the environment was improved: 1946-55, 1956-67, 1968-77, and 1978-84. For the period before 1946, we assumed the same exposure estimates as used for the period 1946-55 by Doll et al. ${ }^{8}$ Cumulative exposure to total nickel, nickel oxide, and soluble nickel was used in the present study to measure the amount of each form to which the men were exposed. The cumulative exposure to metallic and sulphidic nickel were included in the total nickel only. Such exposure was calculated as the product of duration and concentration in each of the 82 working areas for each year.

\section{Results}

The study cohort contributed 125000 personyears, and 1979 deaths from all causes occurred during the follow up period. Table 1 shows the results for cancer incidence. The workers had an increased risk of cancers of the nose and nasal cavities (SIR 18.0, 95\% CI 12-25) and of the lung (SIR 3.0, 95\% CI $2 \cdot 6-3 \cdot 4)$, in which the observed number exceeded the expected by 135 . A significant excess risk was also found for cancer of the prostate (SIR 1.4, 95\% CI 1·2-1·7).

Nickel oxide is the most frequent form of nickel in the roasting and calcining areas of the refinery, with estimated exposures of $10 \mathrm{mg} / \mathrm{m}^{3} /$ year up to 1956 and $5.0 \mathrm{mg} / \mathrm{m}^{3} /$ year in the period 1956-67. Of 32 cases of nasal cancer, 12 were in workers who had a very high cumulative exposure only to nickel oxide, mainly due to work in the roasting and calcining areas (table 2). The table shows that workers with the highest exposure to nickel also have the highest risk of nasal cancer, with a dose-response relation for both nickel oxide and soluble nickel. The risk of nasal cancer seems to diminish, however, as all 32 cases occurred among workers who were first employed before 1956 (data not shown).

Table 3 shows the incidence of lung cancer by year of first exposure for workers exposed to $>0.1 \mathrm{mg} / \mathrm{m}^{3}$ total nickel (182 out of 203 lung cancer cases). Table 3 shows that an excess risk is also present in the group of workers with first employment in 1968 or later. It is

Table 2 Numbers of new cases of nasal cancer among 4764 male nickel refinery workers by cumulative exposure to nickel; follow up $1953-93$

\begin{tabular}{|c|c|c|c|c|c|c|c|c|c|c|c|c|c|c|c|}
\hline \multirow{3}{*}{$\begin{array}{l}\text { Soluble } \\
\text { nickel } \\
\text { compounds } \\
\left(\mathrm{mg} / \mathrm{m}^{3}\right)\end{array}$} & \multicolumn{12}{|c|}{ Cumulative exposure to nickel oxide $\left(\mathrm{mg} / \mathrm{m}^{3}\right)$} & \multirow{2}{*}{\multicolumn{3}{|c|}{ Total }} \\
\hline & \multicolumn{3}{|l|}{0} & \multicolumn{3}{|l|}{$1-4$} & \multicolumn{3}{|c|}{$5-14$} & \multicolumn{3}{|c|}{$\geqslant 15$} & & & \\
\hline & Obs & SIR & $95 \% C I$ & Obs & SIR & $95 \% C I$ & Obs & $S I R$ & $95 \% C I$ & Obs & $S I R$ & $95 \% C I$ & Obs & $S I R$ & $95 \% C I$ \\
\hline $\begin{array}{l}<1 \\
1-4 \\
5-14 \\
\geqslant 15\end{array}$ & $\begin{array}{l}2 \\
0 \\
0 \\
0\end{array}$ & $\begin{array}{l}3 \cdot 6 \\
- \\
-\end{array}$ & & $\begin{array}{l}0 \\
1 \\
0 \\
5\end{array}$ & $\begin{array}{l}\overline{5} \cdot 2 \\
\overline{66} \cdot 0\end{array}$ & & $\begin{array}{l}0 \\
1 \\
1 \\
9\end{array}$ & $\begin{array}{r}- \\
47 \cdot 8 \\
30 \cdot 3 \\
108 \cdot 5\end{array}$ & & $\begin{array}{r}12 \\
0 \\
0 \\
1\end{array}$ & $\begin{array}{l}\frac{44 \cdot 7}{-} \\
\frac{-}{43} \cdot 5\end{array}$ & & $\begin{array}{r}14 \\
2 \\
1 \\
15\end{array}$ & $\begin{array}{r}13 \cdot 7 \\
5 \cdot 1 \\
5 \cdot 5 \\
81 \cdot 7\end{array}$ & $\begin{array}{l}7 \cdot 5-23 \cdot 0 \\
0 \cdot 6-18 \cdot 5 \\
0 \cdot 1-30 \cdot 5 \\
45-135\end{array}$ \\
\hline Total & 2 & $2 \cdot 7$ & $0 \cdot 3-9 \cdot 8$ & 6 & $14 \cdot 3$ & $5 \cdot 2-31 \cdot 2$ & 11 & $40 \cdot 5$ & $20 \cdot 2-72 \cdot 5$ & 13 & $36 \cdot 6$ & $19 \cdot 5-62 \cdot 5$ & 32 & $18 \cdot 0$ & $12 \cdot 3-25 \cdot 4$ \\
\hline
\end{tabular}


Table 3 Numbers of new cases of lung cancer among nickel refinery workers with $\geqslant 0.1 \mathrm{mg} / \mathrm{m}^{3}$ cumulative exposure to nickel, by year of first exposure and year since first exposure; follow up 1953-93

\begin{tabular}{|c|c|c|c|c|c|c|c|c|c|c|c|c|c|c|c|}
\hline \multirow{3}{*}{$\begin{array}{l}\text { Year } \\
\text { of } \\
\text { first } \\
\text { exposure }\end{array}$} & \multicolumn{12}{|c|}{ Time since first exposure $(y)$} & \multirow{2}{*}{\multicolumn{3}{|c|}{ Total }} \\
\hline & \multicolumn{3}{|c|}{$1-14$} & \multicolumn{3}{|c|}{$15-29$} & \multicolumn{3}{|c|}{$30-39$} & \multicolumn{3}{|c|}{$\geqslant 40$} & & & \\
\hline & Obs & $\operatorname{SIR}$ & $95 \% C I$ & Obs & $S I R$ & $95 \% C I$ & Obs & $S I R$ & $95 \% C I$ & Obs & SIR & $95 \% C I$ & Obs & $S I R$ & $95 \% C I$ \\
\hline $\begin{array}{l}1916-44 \\
1945-55 \\
1956-67 \\
1968-83 \\
1916-83\end{array}$ & $\begin{array}{r}0 \\
7 \\
5 \\
6 \\
18\end{array}$ & $\begin{array}{l}- \\
2 \cdot 2 \\
1 \cdot 8 \\
2 \cdot 3 \\
2 \cdot 0\end{array}$ & $\begin{array}{l}0 \cdot 9-4 \cdot 5 \\
0 \cdot 6-4 \cdot 2 \\
0 \cdot 8-4 \cdot 9 \\
1 \cdot 2-3 \cdot 1\end{array}$ & $\begin{array}{r}4 \\
51 \\
23 \\
11 \\
89\end{array}$ & $\begin{array}{l}4 \cdot 1 \\
4 \cdot 4 \\
2 \cdot 9 \\
4 \cdot 0 \\
3 \cdot 8\end{array}$ & $\begin{array}{l}1 \cdot 1-10 \cdot 5 \\
3 \cdot 3-5 \cdot 7 \\
1 \cdot 8-4 \cdot 4 \\
2 \cdot 0-7 \cdot 3 \\
3 \cdot 1-4 \cdot 7\end{array}$ & $\begin{array}{r}14 \\
35 \\
5 \\
54\end{array}$ & $\begin{array}{l}7 \cdot 4 \\
2 \cdot 6 \\
2 \cdot 2 \\
3 \cdot 1\end{array}$ & $\begin{array}{l}4 \cdot 0-12 \cdot 4 \\
1 \cdot 8-3 \cdot 6 \\
0 \cdot 7-5 \cdot 1\end{array}$ & $\begin{array}{r}12 \\
9\end{array}$ & $\begin{array}{l}3 \cdot 4 \\
2 \cdot 7 \\
\frac{-}{3 \cdot 0}\end{array}$ & $\begin{array}{l}1 \cdot 8-6 \cdot 0 \\
1 \cdot 2-5 \cdot 0\end{array}$ & $\begin{array}{r}30 \\
102 \\
33 \\
17 \\
182\end{array}$ & $\begin{array}{l}4 \cdot 7 \\
3 \cdot 2 \\
2 \cdot 6 \\
3 \cdot 2 \\
3 \cdot 2\end{array}$ & $\begin{array}{l}3 \cdot 2-6 \cdot 7 \\
2 \cdot 7-3 \cdot 9 \\
1 \cdot 8-3 \cdot 6 \\
1 \cdot 8-5 \cdot 1 \\
2 \cdot 7-3 \cdot 7\end{array}$ \\
\hline
\end{tabular}

Table 4 Numbers of new cases of lung cancer among male nickel refinery workers according to the cumulative exposure of total nickel; follow up 1953-93

\begin{tabular}{|c|c|c|c|c|c|c|c|c|c|c|c|c|c|c|c|}
\hline \multirow{3}{*}{$\begin{array}{l}\text { Cumula- } \\
\text { tive } \\
\text { exposure to } \\
\text { total nickel } \\
\left(\mathrm{mg} / \mathrm{m}^{3}\right)\end{array}$} & \multicolumn{12}{|c|}{ Time since first exposure $(y)$} & \multirow{2}{*}{\multicolumn{3}{|c|}{ Total }} \\
\hline & \multicolumn{3}{|c|}{$1-14$} & \multicolumn{3}{|c|}{$15-29$} & \multicolumn{3}{|c|}{$30-39$} & \multicolumn{3}{|c|}{$\geqslant 40$} & & & \\
\hline & Obs & SIR & $95 \% C I$ & $O b s$ & $S I R$ & $95 \% C I$ & Obs & $S I R$ & $95 \% C I$ & Obs & SIR & $95 \% C I$ & Obs & $S I R$ & $95 \% C l$ \\
\hline $0 \cdot 1-0.9$ & 1 & $1 \cdot 1$ & $0 \cdot 0-6 \cdot 1$ & 4 & $2 \cdot 5$ & $0.7-6.5$ & 1 & $0 \cdot 8$ & $0 \cdot 0-4 \cdot 8$ & 0 & - & - & 6 & $1 \cdot 4$ & $0.5-3.0$ \\
\hline $1-4$ & 5 & 1.9 & $0 \cdot 6-4 \cdot 3$ & 15 & $3 \cdot 0$ & $1 \cdot 7-5 \cdot 0$ & 3 & $0 \cdot 8$ & $0 \cdot 2-2 \cdot 3$ & 2 & $1 \cdot 3$ & $0 \cdot 1-4 \cdot 6$ & 25 & 1.9 & $1 \cdot 2-2 \cdot 8$ \\
\hline $5-14$ & 5 & 1.9 & $0.6-4.5$ & 17 & $2 \cdot 6$ & $1 \cdot 5-4 \cdot 1$ & 16 & $3 \cdot 3$ & $1 \cdot 9-5 \cdot 3$ & $\tilde{4}$ & $2 \cdot 2$ & $0.6-5.6$ & 42 & $2 \cdot 6$ & $1.9-3.6$ \\
\hline$\geqslant 15$ & 7 & $2 \cdot 4$ & $1 \cdot 0-5 \cdot 0$ & 53 & $5 \cdot 3$ & $4 \cdot 0-7 \cdot 0$ & 34 & $4 \cdot 5$ & $3 \cdot 1-6 \cdot 2$ & 15 & $4 \cdot 8$ & $2 \cdot 7-7 \cdot 9$ & 109 & $4 \cdot 6$ & $3 \cdot 8-5 \cdot 6$ \\
\hline Total & 18 & $2 \cdot 0$ & $1 \cdot 2-3 \cdot 1$ & 89 & $3 \cdot 8$ & $3 \cdot 1-4 \cdot 7$ & 54 & $3 \cdot 1$ & $2 \cdot 3-4 \cdot 0$ & 21 & $3 \cdot 0$ & $1 \cdot 9-4 \cdot 7$ & 182 & $3 \cdot 2$ & $2 \cdot 7-3 \cdot 7$ \\
\hline
\end{tabular}

important to note that all estimated exposures given for this period were based on real measurements of total nickel. For workers with 15-29 years since first exposure, an excess risk was found for all periods of first employment. In the group of workers classified with no exposure to total nickel, 21 cases were observed versus 11.4 expected (data not shown).

An examination of the risk of lung cancer in relation to cumulative exposure to total nickel supports the finding of an excess risk in all periods of follow up (table 4): an increasing risk with increasing exposure was found for all three periods $15-29,30-39$, and $\geqslant 40$ years since first exposure. The SIRs increased from 2.5 to 5.3 in the group $15-29$ and from 0.8 to 4.5 in the group 30-39.

The primary evidence for an excess of lung cancer still came from observations of men

Table 5 Relative risks (RR) of lung cancer by cumulative exposure to soluble nickel and nickel oxide, considering the two variables simultaneously by multivariate Poisson regression analysis *

\begin{tabular}{|c|c|c|c|c|c|}
\hline Variable & $\begin{array}{l}\text { Mean } \\
\text { exposure } \\
\left(\mathrm{mg} / \mathrm{m}^{3}\right)\end{array}$ & Cases (n) & $R R$ & $95 \% C I$ & $\begin{array}{l}\text { Test for } \\
\text { linear trend }\end{array}$ \\
\hline $\begin{array}{l}\text { Soluble nickel } \\
\left(\mathrm{mg} / \mathrm{m}^{3}\right):\end{array}$ & & & & & $P<0.001$ \\
\hline$<1$ & $0 \cdot 1$ & 86 & $1 \cdot 0$ & Referent & \\
\hline $1-4$ & $2 \cdot 3$ & 36 & $1 \cdot 2$ & $0 \cdot 8-1.9$ & \\
\hline $5-14$ & $8 \cdot 8$ & 23 & 1.6 & $1 \cdot 0-2 \cdot 8$ & \\
\hline$\geqslant 15$ & 28.9 & 55 & $3 \cdot 1$ & $2 \cdot 1-4 \cdot 8$ & \\
\hline Nickel oxide & & & & & $P=0.05$ \\
\hline$\underset{<1}{\left(\mathrm{mg} / \mathrm{m}^{3}\right):}$ & 0.4 & 53 & $1 \cdot 0$ & Referent & \\
\hline $1-4$ & 2.5 & 49 & 1.0 & $0.6-1.5$ & \\
\hline $5-14$ & $8 \cdot 3$ & 53 & 1.6 & $1 \cdot 0-2 \cdot 5$ & \\
\hline$\geqslant 15$ & $44 \cdot 3$ & 45 & 1.5 & $1 \cdot 0-2 \cdot 2$ & \\
\hline
\end{tabular}

Adjusted for smoking habits and age

*Workers with unknown smoking habits were excluded (three cases of lung cancer).

Table 6 Relative risks of lung cancer among never and ever smokers in workers exposed to $\geqslant 0 \cdot 1 \mathrm{mg} / \mathrm{m}^{3}$ total nickel; follow up 1953-93*

\begin{tabular}{|c|c|c|c|c|c|c|}
\hline \multirow[b]{2}{*}{ Smoking } & \multicolumn{3}{|c|}{ No exposure } & \multicolumn{3}{|c|}{ Exposure } \\
\hline & $R R$ & Cases (n) & $95 \% C I$ & $R R$ & Cases (n) & $95 \% C I$ \\
\hline $\begin{array}{l}\text { Never } \\
\text { Ever }\end{array}$ & $\begin{array}{l}1 \cdot 0 \\
2 \cdot 9\end{array}$ & $\begin{array}{r}2 \\
18\end{array}$ & $\overline{0 \cdot 6-12 \cdot 3}$ & $\begin{array}{l}1 \cdot 1 \\
5 \cdot 1\end{array}$ & $\begin{array}{r}9 \\
171\end{array}$ & $\begin{array}{l}0 \cdot 2-5 \cdot 1 \\
1 \cdot 3-20 \cdot 5\end{array}$ \\
\hline
\end{tabular}

Adjusted for smoking habits, age, and period.

$\star$ Workers with unknown smoking habits were excluded (three cases of lung cancer). working in the electrolysis department who were exposed to the soluble form of nickel at a concentration of 0.5 to $2.0 \mathrm{mg} / \mathrm{m}^{3}$ and to insoluble forms at $0 \cdot 1-0.5 \mathrm{mg} / \mathrm{m}^{3}$. In a small area in that department (the tankhouse basement) exposure to soluble forms of nickel was estimated to be as high as $2 \cdot 0-8 \cdot 0 \mathrm{mg} / \mathrm{m}^{3}$ during the production period up to 1978 . An analysis was therefore performed to examine the dose-exposure relation for specific forms of nickel after adjustment for the other form (table 5). Workers with the highest cumulative soluble exposures of $\geqslant 15 \mathrm{mg} / \mathrm{m}^{3}$ nickel had a threefold increase in $R R$ in comparison with the reference population and a significant trend $(P<0.001)$. There is also some evidence to suggest that long-term exposure to nickel oxide is related to an excess risk of lung cancer, with a $50 \%$ increase in relative risk (test for linear trend, $\mathrm{P}=0.05$ ).

Out of the total of 203 cases of lung cancer, 189 were in workers classified as ever smokers and 11 cases in the group of never smokers. In table 6 , the relative risks for the groups of smokers not exposed and exposed to nickel are compared with the group of never smokers not exposed to nickel. The relative risks for the two groups of smokers were 2.9 and $5 \cdot 1$ respectively, suggesting a multiplicative effect of smoking on the effect of occupational exposure to nickel. The cohort of nickel refinery workers was also compared with a sample from the general population. The group of never smokers not exposed to nickel in the general population was used for reference. The group of smokers not exposed to nickel had an RR of $6 \cdot 1(95 \%$ CI $3 \cdot 0-12 \cdot 4)$, whereas the two groups of workers exposed to nickel had an RR of $3.6(95 \% \mathrm{CI} 1 \cdot 1-12)$ and 23 (95\% CI 11 48) for the never smoking and smoking groups, respectively.

\section{Discussion}

The main purpose of this study was to obtain a better understanding of human risk of respiratory cancer associated with exposure to the 
different forms of nickel occurring in this nickel refinery, and to study the interaction between nickel exposure and smoking. The results from the extended follow up show a consistent increase in the risk of lung cancer as reported previously, ${ }^{\circ}$ but also among those with first exposure after 1968, when the environment was improved. The study gave strong evidence of a relation between exposure to soluble nickel and lung cancer when either internal or external controls were used; whereas the evidence was not so strong for oxidic nickel. However, there was some evidence to suggest that oxidic nickel is a stronger hazard for nasal cancer than soluble nickel, as 12 cases $(0 \cdot 27$ expected) out of the 32 occurred among workers exposed mostly to nickel oxides. The results also suggest a multiplicative effect of the risk of lung cancer from smoking and total exposure to nickel.

An increased risk of lung cancer among workers exposed to soluble nickel was also found in the data from Clydach, ${ }^{12}$ after reanalyses by Doll et al. ${ }^{8}$ Exposure to both forms of nickel was common in both refineries up to 1929; however, the Clydach refinery changed their technology in $1930,{ }^{2}$ whereas the workers included in the present study continued to be exposed to high concentrations of soluble forms of nickel until 1978. No excess risk of lung cancer was found among electrolysis workers in the Port Colborne refinery ${ }^{7}$ or in the Finnish refinery, ${ }^{21}$ but workers in these two factories had been exposed to a lower concentration of soluble nickel in the general electrolysis department $\left(<0.3 \mathrm{mg} / \mathrm{m}^{3}\right.$ nickel in Port Colborne and $<0.5 \mathrm{mg} / \mathrm{m}^{3}$ nickel in Finland).

In our previous two papers, no excess risk of lung cancer was found among those with first entry in 1968 or later, when exposure to insoluble forms of nickel was reduced. The improvement in working conditions, however, did not reduce the risk of lung cancer as workers first exposed after that date still had the same high risk as workers exposed in previous years (table 3). It is important to note that the estimates used for this period were based primarily on real measurements obtained in 1973. If the relation between exposure to soluble nickel and lung cancer is causal, a decrease in incidence cannot be expected in workers exposed before 1978, when improvements were made to reduce exposure to soluble nickel. All of the 17 workers with lung cancer who were first exposed after 1968 were also first exposed before 1978. As the expected number of cases of lung cancer among those first exposed in 1978 or later is only 0.43 , an extended follow up of lung cancer is necessary before a final conclusion can be drawn.

Use of a job exposure matrix in epidemiological studies is important, but its value depends on its ability to distinguish between truly exposed and unexposed people. ${ }^{22}$ The process steps in a nickel refinery are complex, and it was therefore difficult to identify working areas where exposure was exclusively to soluble or insoluble nickel compounds. In this study, the estimates were usually first made for small working areas, before the estimates were combined into broader groups exposed at the same level over time. A weakness of the method, as also used in other similar studies, ${ }^{823}$ was that all the measurements were based on total nickel concentration. It was assumed that the nickel species occurred in respirable dust in the same proportion as in the material being handled in the various work areas. Some amount of soluble nickel may also have occurred in the calcining and roasting departments. Recent measurements of flue dust in the gas handling system indicate that there was some nickel sulphate in these working areas. An underestimate of the concentration of soluble nickel in the calcining and roasting departments would certainly not affect the overall conclusions, but would indicate that soluble nickel may have been important in these working areas as well.

In the group of workers classified with no nickel exposure, 21 cases of lung cancer were observed (SIR 1.8, 95\% CI 1.1-2.8). This group of men also included workers in various maintenance shops. They have been exposed to asbestos and for periods also to nickel. For many years asbestos was widely used at the refinery and all the three cases of malignant mesothelioma in the present study were in this subgroup. As no cases of this disease were found among workers in the calcining or electrolysis department it is unlikely that exposure to asbestos could explain the overall increased risk of lung cancer at the refinery.

Unlike our previous findings, ${ }^{\circ}$ evidence from this study suggests a multiplicative effect on lung cancer of exposure to total nickel and smoking. In our report of 1982 we concluded that smoking had an additive effect with occupational exposure to nickel. The workers exposed to nickel were, however, classified differently in the two studies: in the first study all employees were included. In the present study, only those workers with a cumulative exposure to $\geqslant 0.1 \mathrm{mg} / \mathrm{m}^{3}$ nickel in total were included in this analysis; furthermore, all of the data on smoking were checked in the medical file, except for those 159 obtained through interview.

Although occupational exposure may cause lung cancer, cigarette smoking is a more important factor. ${ }^{24}$ In the present study, smoking in combination with exposure to nickel seems to interact, creating an exceedingly high risk of lung cancer for workers who both smoked and were exposed to nickel (table 6). The results indicate a multiplicative effect, but a weakness is certainly the small numbers in the two never smoker groups with only two and nine cases in the unexposed and the exposed groups of workers, respectively. A multiplicative effect was also found in the analysis that used data on smoking from the population based sample ${ }^{16}$ when the men who never smoked in the general population were used as a reference. Few studies of nickel refinery workers have data on smoking. In the case-control study from New Caledonia, no firm evidence could be drawn of exposure to nickel and smoking as the study was based on few cases. ${ }^{25}$ Coultas and Samet reported that 
the only interactions between smoking and an occupational exposure known to affect lung cancer are those with asbestos or radon..$^{26}$ Our findings may be added to that list.

An excess in incidence of nasal cancer was found in almost all studies of nickel refinery workers. ${ }^{125-8}$ All of the cases of nasal cancer in the present study occurred in workers first employed before 1956 . The material handled in the roasting department was changed in 1954 when arsenic was almost entirely removed. Arsenic is a well known carcinogen, but has not been reported to cause nasal cancer. ${ }^{27}$ There is some evidence that oxidic nickel at the highest cumulative exposure $\left(>15 \mathrm{mg} / \mathrm{m}^{3}, 12\right.$ observed $v 0.27$ expected, table 2) is a stronger hazard than soluble nickel. There is also evidence that exposure to both soluble nickel at the highest cumulative exposure $\left(>15 \mathrm{mg} / \mathrm{m}^{3}\right.$ ) and oxidic nickel is more strongly associated with nasal cancer than soluble nickel alone (table 2).

Cancer of the prostate was also found in excess. Incidence reports from the Cancer Registry show geographical variation in the incidence of prostate cancer ${ }^{28}$; the incidence in the southern part of Norway, where the factory is located, being $20 \%-30 \%$ higher than in the whole country. This difference could explain almost all of the increased risk. This is possibly due to more intensive diagnostics, as the death rate from prostatic cancer in the region is similar to that for the total population. ${ }^{29}$

The present study confirms the results of our previous reports on the cancer risk associated with exposure to soluble forms of nickel and indicates risks also in working areas with exposure to soluble nickel and exposure to other forms of nickel. An excess risk of lung cancer was found among nickel refinery workers in Norway even when employment started after 1968. It is not possible to state with certainty which specific nickel compounds are carcinogenic, but a significant excess risk was found for workers exposed to soluble nickel alone or in combination with other forms of nickel. The present study also suggests a multiplicative effect between smoking and exposure to nickel. Whether smoking is a requirement for the risk of lung cancer in nickel refinery workers remains to be seen.

We express gratitude to P G Thornhill and A Cecutti of Falconbridge Canada, for their valuable work with the exposure matrixes; Thornhill also chaired the group of experts. We also express thanks to I Andersen, Falconbridge, Kristiansand who participated in the expert group and assisted us with data on the cohort, and to the late A C Hogetveit. Thanks are also given to Elisabeth Heseltine for revision of the manuscript and Tor Haldorsen of The Cancer Registry for his comments.
1 Bridge JC. Annual report of the chief inspector of the year 1932 London: HMSO 1933:103.

2 Doll R. Cancer of the lung and nose in nickel workers. $\mathrm{Br} F$ Ind Med 1958;15:217-23.

3 Mastromatteo E. Nickel: a review of its occupational health aspects. F Occup Med 1967;9:127-36.

4 Loken $\mathrm{Aa} \mathrm{Ch}$. Lungecarcinom hos nikkelarbeidere. Tidsskr Nor Logeforen 1950;70:376-8. (In Norwegian.)

5 Pedersen E, Hogetveit AC, Andersen Aa. Cancer of respiratory organs among workers at a nickel refinery in Norway. Int $\mathcal{F}$ Cancer 1973;12:32-41.

6 Magnus K, Andersen Aa, Høgetveit AC. Cancer of respiratory organs among workers at a nickel refinery in tory organs among workers at a

7 Roberts RS, Julian JA, Muir DCF, Shannon H. Cancer mortality associated with high-temperature oxidation of nickel sub-sulfide. In: Sunderman FW. Nickel in the human environment. Lyon: International Agency for Research on Cancer, 1984

8 Doll R, Andersen Aa, Cooper WC, Cosmatos I, Cragle $\mathrm{DL}$, Easton D, et al. Report of the International Committee on Nickel Carcinogenesis in Man. Scand 7 Work Environ Health 1990;16(suppl):1-82.

9 International Agency for Research on Cancer. Chromium, nickel and welding. LARC Monogr Eval Carcinog Risks Hum 1990;49:257-445.

10 Sunderman FW, Aitio A, Morgan LG, Norseth T. Biological monitoring of nickel. Toxicol Ind Health Biological mo

11 DiPaolo JA, Casto BC. Quantitative studies of in vitro morphological transformation of Syrian hamster cells by inorganic metal salts. Cancer Res 1979;39:1008-13.

12 Sunderman FW, Hopfer SM, Knight JA, McCully KS Cecutti AG, Thornhill PG, et al. Physicochemical characteristics and biological effects of nickel oxides. Carcinogenesis 1987;8:305-13.

13 Dunnick JK, Elwell MR, Radovsky AE, Hahn FF, Nikula $\mathrm{KJ}$, Barr EB, et al. Comparative carcinogenic effects of nickel subsulfide, nickel oxide, or nickel sulfate hexahydrate chronic exposures in the lung. Cancer Res 1995;55: drate ch

14 Costa M, Salnikow K, Cosentino S, Klein CB, Huang X, Zhuang Z. Molecular mechanisms of nickel. Environ Health Perspect 1994;102(suppl 3):127-30

15 Rønneberg A, Lund KE, Hafstad A. Lifetime smoking habits among Norwegian men and women born between 1890 and 1974. Int f Epidemiol 1994;23:267-75.

16 Lund E, Zeiner-Henriksen T. Smoking as risk factor for cancer among 26000 Norwegian males and females. Tidsskr Nor Logeforen 1981;34-6:1937-40. (In Norwegian.)

17 Preston DL, Lubin JH, Pierce DA, McConney ME. Epicure, Seattle: Hirosoft, 1993.

18 EGRET. Statistical software. Seattle: Statistics and Epidemiology Research, 1988.

19 Archibald FR. The Kristiansand nickel refinery. Fournal of Metals 1962;14:648-52.

20 Glømme, J. Arbeidshygieniske undersøkelser over virkningen av irriterende gasser og forskjellige partikulore forurensninger arbeidsatmosforen $i$ en norsk elektrokjemisk industri. Vol 1. Oslo: Institute of Occupational Health, 1967. (In Norwegian.)

21 Karjalainen S, Kerttula R, Pukkala E. Cancer risk among workers at a copper/nickel smelter and nickel refinery in

22 Stewart PA, Herrick RF. Issues in performing retrospective exposure assessment. Appl Occup Environ Hyg 1991;6: 421-7.

23 Shannon HS, Walsh C, Jadon N, Julian JA, Weglo JK, Thornhill PG, et al. Mortality of 11500 nickel workersextended follow up and relationship to environmental conditions. Toxicol Ind Health 1991;7:277-94.

24 US Department of Health and Human Services, Public Health Service. The health consequences of smoking: cancer and chronic lung disease in the workplace. $A$ report of the Surgeon General. Washington, DC: US Government Printing Office, DHHS (PHS), 1985;85:50207.

25 Lessard R, Reed D, Maheux B, Lambert J. Lung cancer in New Caledonia, a nickel smelting island. 7 Occup Med 1978;20:815-7.

26 Coultas DB, Samet JM. Occupational lung cancer. Occup Lung Dis1992;13:341-54.

27 IARC. Overall evaluations of carcinogenicity: an updating of IARC monographs vols 1 to 42. LARC Monogr Eval Carcinog Risks Hum Suppl 1987;7:100-6.

28 The Cancer Registry of Norway. Incidence of cancer in Norway 1982-6. Oslo: CRN, 1989.

29 Central Bureau of Statistics of Norway. Causes of deaths 1989. Oslo. CBN, 1990. (ISBN 82-537-3012-8.) 